\title{
Pengaruh penambahan sari nanas terhadap karakteristik kimia dan sensori minuman teh cascara
}

\author{
The effect of pineapple juice additions on the chemical characteristics and sensory of \\ cascara tea drinks
}

\author{
Wiwik Endah Rahayu ${ }^{1)}$, Rita Purwasih ${ }^{1)}$, Dandy Hidayat ${ }^{1)}$ \\ ${ }^{1}$ Politeknik Negeri Subang \\ *email : windayu.sk@gmail.com \\ Informasi artikel \\ Dikirim: 08/03/2020; ditinjau: 09/03/2020; disetujui: 09/09/2020
}

\begin{abstract}
Cascara tea is a drink made from dry coffee skin from coffee beans stripping process result. The aim of this research is to study the effect of pineapple juice on chemical characteristics (Total Tated Acid (TAT), vitamin $C, p H$ ) and sensory test results of cascara tea drinks. The experimental design used was a complete randomized design with 3 treatment and 3 replications. The treatment used is T1: Control (without adding pineapple juice), T2: Add pineapple juice $25 \%$, T3: Add pineapple juice $35 \%$. The parameters observed are the chemical characteristics of TAT, vitamin $C$, and $p H$, also sensory test of color, taste, aroma, and overall appearance. The resulting data was analyzed by Variant Analysis (ANOVA) with a significance level of 5\% and continue with the Duncan test. The results of experiments showed a addition of pineapple juice gave a significant value of TAT, vitamin $C$, and $p H$ of cascara tea drinks $(P<0.05)$. Sensory test results showed that pineapple juice addition gave significant value ( $P$ $<0.05)$ for aroma, taste, and appearance overal and no significant effect $(P>0.05)$ for the color. $35 \%$ addition of cascara tea liked by panelis. Cascata tea drinks has chemical characteristics, TAT 0.18-0.26\%; vitamin C levels 49,37-68,87 ml / 100g; and pH 3.89-4.04.
\end{abstract}

Keywords: cascara, $p H$, pineapple juice, TAT, vitamin $C$.

\begin{abstract}
ABSTRAK
Minuman teh cascara adalah minuman yang terbuat dari limbah kulit kopi yang dikeringkan dari hasil proses pengupasan buah kopi. Tujuan penelitian adalah mengetahui pengaruh penambahan sari nanas terhadap karakteristik kimia (Total Asam Tertitrasi (TAT), vitamin $\mathrm{C}, \mathrm{pH}$ ) dan hasil uji sensori minuman teh cascara. Rancangan percobaan yang digunakan yaitu Rancangan Acak Lengkap dengan 3 perlakuan dan 3 kali ulangan. Perlakuan yang digunakan yaitu T1: Kontrol (tanpa penambahan sari nanas), T2: Penambahan sari nanas $25 \%$, T3: Penambahan sari nanas $35 \%$. Parameter yang diamati yaitu karakteristik kimia meliputi TAT, vitamin $\mathrm{C}$, dan $\mathrm{pH}$, serta uji sensori meliputi warna, rasa, aroma, dan kenampakan keseluruhan. Data yang dihasilkan dianalisis dengan Analysis of Variance (ANOVA) dengan taraf signifikasi 5 dan dilanjutkan dengan uji Duncan. Hasil percobaan menunjukkan bahwa penambahan sari nanas memberikan pengaruh nyata $(\mathrm{P}<0,05)$ terhadap nilai TAT, vitamin $\mathrm{C}$, dan $\mathrm{pH}$ minuman teh cascara. Hasil uji sensori menunjukkan bahwa penambahan sari nanas memberikan pengaruh nyata $(\mathrm{P}<0,05)$ terhadap aroma, rasa, dan kenampakan keseluruhan sedangkan untuk warna tidak berpengaruh nyata $(\mathrm{P}>0,05)$. Minuman teh cascara dengan penambahan sari nanas sebanyak $35 \%$ merupakan minuman yang
\end{abstract}


disukai panelis. Minuman teh cascara memiliki karekteristik kimia yaitu TAT 0,180,26\%; kadar vitamin C 49,37-68,87 ml/100g; dan $\mathrm{pH} 3,89-4,04$.

Kata kunci : cascara, $\mathrm{pH}$, sari nanas, TAT, vitamin C.

\section{PENDAHULUAN}

Nanas merupakan salah satu komoditi hortikultura yang banyak ditemukan di wilayah tropis salah satunya di kabupaten Subang. Nanas memiliki kandungan di antaranya vitamin A, kalsium, fosfor, magnesium, besi, kalium, dekstrosa, sukrosa, serta enzim bromelin (Hayat et al., 2015). Selain karena kandungan nutrisi yang tinggi, nanas juga banyak digemari oleh masyarakat sehingga nanas mempunyai potensi pasar yang tinggi. Namun demikian jika dijual dalam bentuk buah segar, nanas mudah mengalami penurunan kualitas baik karena pengaruh fisika ataupun pengaruh biologi sehingga buah nanas busuk. Untuk mengatasi hal tersebut dan upaya untuk diversifikasi produk, nanas seringkali dimanfaatkan untuk produk minuman salah satunya adalah sari buah nanas (Sugiyono, 2013). Sari buah nanas adalah cairan yang dihasilkan dari proses pengepresan daging buah nanas dilanjutkan dengan proses sesuai dengan kategorinya. Sari buah nanas sendiri dikategorikan menjadi 2 yaitu sari buah encer dan sari buah pekat atau sirup. Sari buah nanas encer diperoleh dari proses pengepresan buah nanas dilanjutkan dengan penambahan air dan gula pasir, sedangkan sari buah pekat atau sirup diperoleh dari proses pengepresan daging buah dilanjutkan dengan proses pemekatan baik dengan menggunakan cara pendidihan ataupun yang lainnya (Juansah et al., 2009). Sari buah nanas memiliki rasa yang sama dengan buah nanas sehingga sering ditambahkan pada pengolahan produk tertentu yang dapat menambah cita rasa dan kandungan gizi suatu produk tersebut.

Cascara merupakan kulit kering dari buah kopi yang dapat diolah menjadi produk yang memiliki nilai tambah. Namun demikian, oleh masyarakat umum pemanfaatan cascara di bidang pangan sendiri masih kurang, cascara biasanya dimanfaatkan untuk pakan ternak ataupun pupuk kompos (Sari et al., 2019). Seiring dengan perkembangan teknologi dibidang pangan, dewasa ini cascara sudah diolah menjadi produk minuman. Salah satu produk minuman cascara yaitu teh celup, berdasarkan hasil uji hedonik yang dilakukan teh celup cascara cukup disukai oleh masyarakat (Garis et al., 2019). Teh cascara merupakan produk teh berbahan dasar limbah kulit kopi yaitu cascara yang dikeringkan dari hasil proses pengupasan buah kopi (Putri \& Anggraeni, 2017). Pemanfaatan cascara menjadi teh karena cascara memiliki cita rasa dan aroma yang kuat dan dimungkinkan memiliki sedikit kandungan antioksidan. Antioksidan dapat berperan sebagai pengikat radikal bebas yang masuk ke dalam tubuh (Wathon, 2019). Cascara juga mengandung kafein, lignin, dan tannin. Tannin merupakan senyawa polifenol yang dapat ditemui pada semua jenis tanaman, keberadaan tannin ini dapat menyebabkan rasa sepet (Oktadina et al., 2013). Untuk itu harus ada bahan tambahan sebagai upaya diversifikasi produk dan memperbaiki cita rasa yang ada pada teh cascara.

Teh cascara dengan penambahan sari nanas merupakan inovasi baru dalam pembuatan teh cascara. Penambahan sari nanas pada teh cascara diharapkan juga mampu menambah cita rasa dan kandungan gizi minuman cascara. Tujuan dari penelitian ini adalah mengetahui karakteristik kimia dan uji sensori minuman teh cascara dengan penambahan sari buah nanas.

\section{METODE}

\section{Bahan}

Bahan yang digunakan dalam pembuatan minuman teh cascara dengan penambahan sari nanas antara lain teh cascara, sari buah nanas, dan gula.

\section{Alat \\ Alat-alat yang diperlukan dalam proses pembuatan minuman teh cascara dengan}


penambahan sari buah nanas di antaranya timbangan, blender, gelas ukur, sendok, wajan, kompor, spatula, dan baskom.

\section{Metode pelaksanaan}

Proses pembuatan minuman teh cascara dengan penambahan sari buah nanas dilakukan dengan beberapa tahap yaitu tahap pembuatan teh cascara, tahap pembuatan sari sari buah nanas, tahap pencampuran atau pembuatan minuman teh cascara dengan penambahan sari buah nanas, dan tahap pengujian.

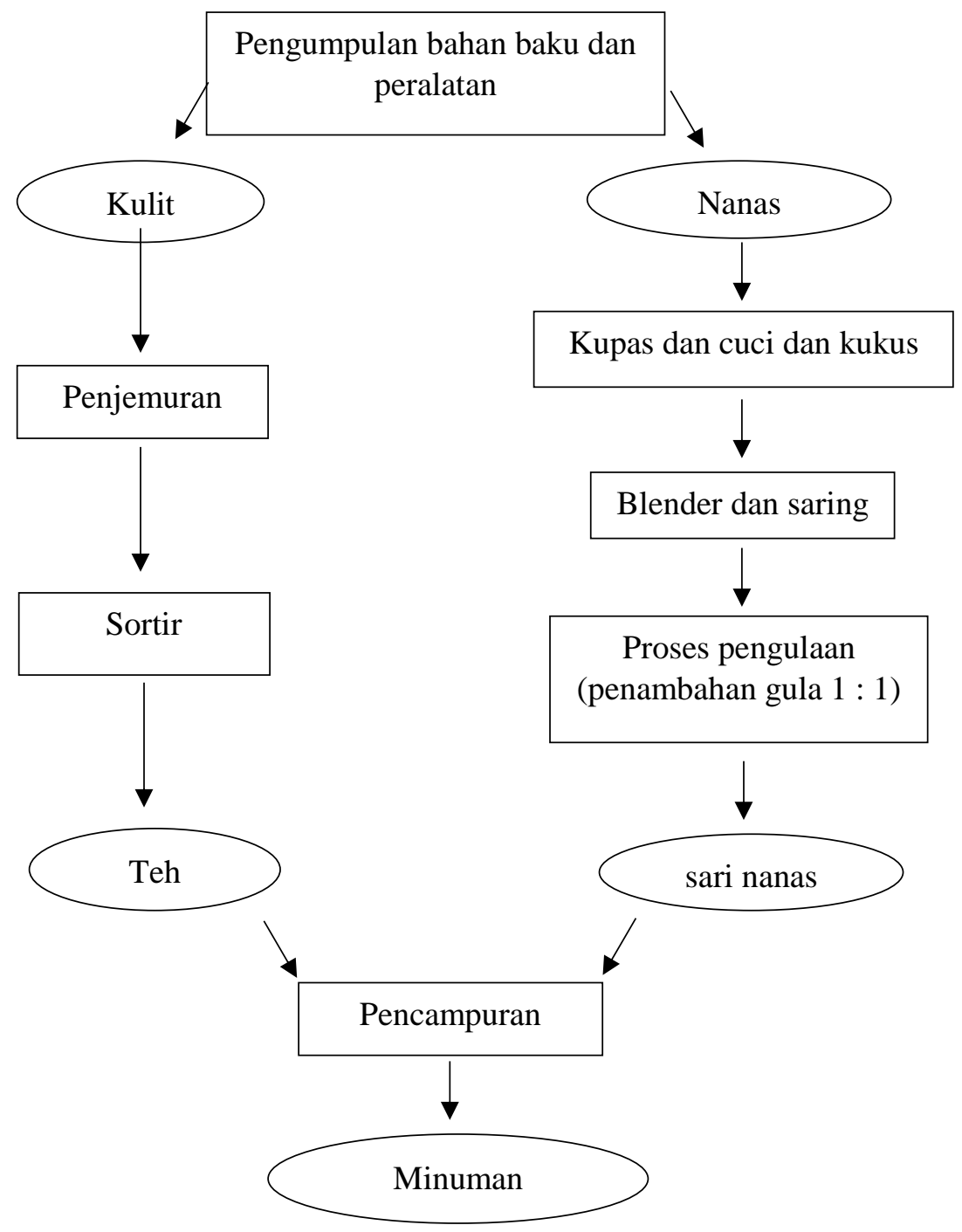

Gambar 1. Diagram alir proses pembuatan minuman teh cascara

\section{Pembuatan teh Cascara}

Proses pembuatan teh cascara terdiri dari persiapan alat dan bahan, penjemuran cascara dengan sinar matahari 15 hari, penyortiran dengan tujuan untuk memisahkan cascara dari kotoran-kotoran yang ada hal ini dilakukan untuk menjaga kualitas teh pada saat penyeduhan agar tidak terkontaminasi benda lain, penyimpanan dalam suhu ruang untuk tetap menjaga kualitas cascara tersebut.

\section{Pembuatan sari nanas}

Terdiri dari tahap persiapan alat dan bahan, pengupasan, pencucian buah nanas, proses pembuatan bubur nanas dilakukan dengan memblender nanas yang sudah dikukus setelah menjadi bubur nanas lalu di saring untuk mendapatkan sari nanas dan memisahkan ampasnya, proses selanjutnya adalah proses penggulaan yaitu dengan melakukan pemasakan bubur nanas dan penambahan gula sambil diaduk untuk 
menghomogenkan sari nanas dan gula, dan pengemasan

\section{Pembuatan minuman teh Cascara dengan penambahan sari nanas}

Proses pembuatan minuman teh cascara dengan penambahan sari nanas dilakukan dengan tahap perisapan alat dan bahan, penyeduhan teh cascara penyeduhan ini harus dibiarkan minimal 15 menit, hal tersebut dikarenakan teh cascara mempunyai ukuran yang besar dibandingkan teh biasanya oleh karena itu memerlukan waktu sedikit lebih lama untuk proses ektraksinya. Perbandingan teh cascara dan air seduhan yaitu $1: 10$, terakhir adalah penambahan sari sari nanas sesuai dengan perlakuan.

\section{Rancangan penelitian}

Penelitian ini menggunakan Rancangan Acak Lengkap (RAL) dengan 3 perlakuan dan 3 kali ulangan yaitu sebagai berikut:

$\mathrm{T}_{1}$ : Kontrol (tanpa penambahan sari nanas)

$\mathrm{T}_{2}$ : Teh cascara dengan penambahan sari nanas $25 \%$

$\mathrm{T}_{3}$ : Teh cascara dengan penambahan sari nanas $35 \%$

\section{Parameter yang diamati}

Parameter yang diukur meliputi analisis TAT, vitamin $\mathrm{C}$, $\mathrm{pH}$, dan uji hedonik dengan menggunakan metode skoring (warna, aroma, rasa, dan kenampakan keseluruhan). Panelis yang digunakan adalah tidak terlatih dengan jumlah 28 orang. Adapun rentang penilaian uji hedonik yang digunakan yaitu sangat suka (5), suka (4), cukup suka (3), tidak suka (2) dan sangat tidak suka (1).

\section{Analisis data}

Data uji hedonik ditransformasi terlebih dahulu menggunakan metode akar dengan rumus $=\operatorname{SQRT}($ data $+0,5)$. Selanjutnya, semua data dianalisis dengan analysis of varian (ANOVA) dengan taraf signifikasi $5 \%$, jika terdapat pengaruh yang nyata dilanjut dengan uji Duncan, pengolahan data menggunakan IBM SPSS Statistics Version 23.

\section{HASIL DAN PEMBAHASAN}

Penambahan sari nanas berpengaruh $(\mathrm{P}>0,05)$ terhadap nilai TAT, vitamin $\mathrm{C}$, dan $\mathrm{pH}$ minuman teh cascara. Hasil pengukuran TAT, vitamin $\mathrm{C}$, dan $\mathrm{pH}$ dapat dilihat pada Tabel 1.

Tabel 1. Hasil pengujian karakteristik kimia minuman teh cascara

\begin{tabular}{cccc}
\hline \multirow{2}{*}{ Perlakuan } & \multicolumn{3}{c}{ Parameter } \\
\cline { 2 - 4 } & TAT (\%) & $\begin{array}{c}\text { Vitamin C } \\
(\mathbf{m l} / \mathbf{1 0 0 g r a m})\end{array}$ & pH \\
\hline T1 & $0,18 \pm 0,01^{\mathrm{a}}$ & $49,37 \pm 3,97^{\mathrm{a}}$ & $4,04 \pm 0,01^{\mathrm{c}}$ \\
T2 & $0,24 \pm 0,01^{\mathrm{b}}$ & $57,73 \pm 3,79^{\mathrm{b}}$ & $3,93 \pm 0,01^{\mathrm{b}}$ \\
T3 & $0,26 \pm 0,01^{\mathrm{c}}$ & $68,87 \pm 1,36^{\mathrm{c}}$ & $3,89 \pm 0,00^{\mathrm{a}}$ \\
\hline
\end{tabular}

Keterangan: T1: Kontrol (tanpa penambahan sari nanas), T2: Dengan penambahan sari nanas $25 \%$, T3: Dengan penambahan sari nanas $35 \%,{ }^{\text {a,b,c }}$ : Superscript yang berbeda menunjukkan perbedaan nyata $\mathrm{P}(>0,005)$

\section{TAT}

Berdasarkan hasil analisis ragam menunjukkan bahwa minuman teh cascara dengan penambahan sari nanas memberikan pengaruh nyata $(\mathrm{P}<0,05)$ terhadap hasil TAT. Persentase hasil TAT tertinggi terdapat pada T3 yaitu $0,26 \%$ dibandingkan dengan T2 yaitu $0,24 \%$ dan T1 yaitu $0,18 \%$. Semakin banyak penambahan sari nanas maka pada hasil TAT akan semakin tinggi. Perbandingan antara bahan baku dalam suatu minuman yang mengandung asam sitrat tinggi sebagai asam organik yang dominan akan berpengaruh terhadap peningkatan total asam yang terkandung dalam minuman tersebut. Perbandingan antara sari sirsak dan sari bit memberikan pengaruh sangat nyata ( $\mathrm{P}>0,01)$ terhadap total asam sirup yang dihasilkan (Bastanta et al., 2017). Nanas memiliki kandungan asam sitrat yang sangat tinggi yaitu sekitar $87 \%$ dari total asam yang terkandung di dalamnya sehingga dapat 
meningkatkan TAT cascara (Kamaluddin \& Handayani, 2018). Menurut Daniela, Lubis, \& Nainggolan (2015) bahwa kandungan asam sitrat dan asam malat yang terkandung dalam buah nanas akan mempengaruhi TAT pada suatu bahan (Aulya Rohmana et al., 2015).

\section{Vitamin C}

Berdasarkan hasil analisa ragam menunjukkan bahwa minuman teh cascara dengan penambahan sari nanas memberikan pengaruh nyata $(\mathrm{P}<0,05)$ terhadap kandungan vitamin $\mathrm{C}$ minuman teh cascara. Hasil kandungan vitamin $\mathrm{C}$ tertinggi terdapat pada T3 yaitu $68,87 \mathrm{ml} / 100 \mathrm{~g}$ dibandingkan dengan $\mathrm{T} 2$ yaitu $57,73 \mathrm{ml} / 100 \mathrm{~g}$ dan $\mathrm{T} 1$ yaitu $49,37 \mathrm{ml} / 100$ g. Semakin banyak penambahan sari nanas maka kandungan vitamin $\mathrm{C}$ pada minuman tersebut akan semakin tinggi. Vitamin $\mathrm{C}$ pada minuman dipengaruhi oleh kandungan vitamin $\mathrm{C}$ dalam bahan bakunya (Kumalasari et al., 2015). Oksidasi asam askorbat atau vitamin $\mathrm{C}$ dapat dihambat penurunannya dengan asam sehingga kadar vitamin $\mathrm{C}$ dapat dipertahankan (Kamaluddin \& Handayani, 2018). Hasil tersebut sesuai pendapat Wiyono \& Kartikawati (2017) yang menyatakan bahwa kandungan vitamin C pada nanas tergolong tinggi $6,38 \mathrm{ml} / 100 \mathrm{~g}$ sehingga akan berpengaruh terhadap bahan yang akan dicampurkannya, dan pendapat Daniela et al. (2015) yang menyatakan bahwa nanas memiliki kandungan vitamin $\mathrm{C}$ yang tinggi yaitu $80 \%$ dan mengakibatkan pengaruh terhadap bahan yang dicampurkannya.

pH

Berdasarkan hasil analisa ragam menunjukkan bahwa minuman teh cascara dengan penambahan sari nanas memberikan pengaruh nyata $(\mathrm{P}<0,05)$ terhadap nilai $\mathrm{pH}$. Hasil nilai pH T1 yaitu 4,04, T2 yaitu 3,93, dan T3 yaitu 3,89. Semakin banyak penambahan sari nanas akan semakin asam minuman teh cascara dan menurunkan $\mathrm{pH}$ teh cascara. Hal tersebut karena penambahan sari nanas yang memiliki kandungan asam tinggi sehingga berpengaruh terhadap nilai $\mathrm{pH}$ minuman teh cascara. Nilai $\mathrm{pH}$ di dalam penelitian ini 3,89-4,04 lebih rendah dibandingkan penelitian yang dilakukan oleh (Sari et al., 2019) yaitu 4,42-4,30 dengan menggunakan konsentrasi gula dengan sirup kulit nanas dan kopi. Menurut Nurman, Muhajir, \& Muhardina (2018) bahwa pengaruh $\mathrm{pH}$ disebabkan oleh kandungan asam sitrat dan asam malat yang terdapat dalam buah nanas berubah menjadi asam laktat selama masa produksi. Sedangkan menurut Aulya Rohmana et al. (2015) bahwa pengaruh $\mathrm{pH}$ disebabkan oleh kandungan asam yang terkandung dalam buah nanas. $\mathrm{pH}$ buah nanas yang digunakan sekitar 3,71 sehingga dapat mempengaruhi nilai $\mathrm{pH}$ pada bahan yang dicampurkannya.

\section{Uji sensori}

Berdasarkan hasil uji sensori yang dilakukan terhadap minuman dengan penambahan sari nanas tersaji pada Tabel 2 .

Tabel 2. Hasil uji sensori minuman teh cacsara

\begin{tabular}{|c|c|c|c|c|}
\hline \multirow[b]{2}{*}{ Perlakuan } & \multicolumn{3}{|c|}{ Parameter } & \multirow[b]{2}{*}{$\begin{array}{l}\text { Kenampakan } \\
\text { Keseluruhan }\end{array}$} \\
\hline & Warna & Aroma & Rasa & \\
\hline $\mathrm{T} 1$ & $3,80 \pm 0,22^{\mathrm{a}}$ & $3,10 \pm 0,22^{\mathrm{a}}$ & $1,80 \pm 0,22^{\mathrm{a}}$ & $3,50 \pm 0,20^{b}$ \\
\hline $\mathrm{T} 2$ & $3,50 \pm 0,16^{\mathrm{a}}$ & $3,60 \pm 0,18^{b}$ & $3,20 \pm 0,22^{b}$ & $3,20 \pm 0,17^{\mathrm{ab}}$ \\
\hline $\mathrm{T} 3$ & $3,50 \pm 0,20^{\mathrm{a}}$ & $3,70 \pm 0,21^{\mathrm{b}}$ & $3,90 \pm 0,19^{c}$ & $2,90 \pm 0,23^{\mathrm{a}}$ \\
\hline
\end{tabular}

Keterangan : T1: Kontrol (tanpa penambahan sari nanas), T2: Dengan penambahan sari nanas $20 \%$, T3: Dengan penambahan sari nanas $35 \%,{ }^{\mathrm{a}, \mathrm{b}, \mathrm{c}}$ : Superscript yang berbeda menunjukkan perbedaan nyata $\mathrm{P}(>0,005)$

\section{Warna}

Hasil analisis uji sensori menunjukkan bahwa minuman teh cascara dengan penambahan sari nanas tidak berpengaruh nyata $(\mathrm{P}>0,05)$ terhadap warna yang dihasilkannya. Berdasarkan hasil uji sensori yang terdapat pada Tabel 2 didapatkan bahwa T1 memiliki skor tertinggi yaitu 3,80 
(suka), T2 memiliki skor 3,50 (suka), dan untuk T3 memiliki skor 3,50 (suka). Hal tersebut sesuai dengan penelitian yang dilakukan oleh (Sari et al., 2019) pembuatan teh cascara dan air dengan konsentrasi gula yang berbeda tidak berpengaruh nyata $(\mathrm{P}>0,05)$ terhadap warna sirup kulit kopi. Penambahan sari nanas menimbulkan perubahan warna pada teh cascara yang asalnya berwarna cokelat menjadi berwarna cokelat kekuningan. Hal tersebut disebabkan oleh terdegradasinya pigmen karatenoid dan xantofil yang terkandung dalam nanas sehingga tidak mempengaruhi tingkat kesukaan panelis terhadap warna minuman teh cascara dengan penambahan sari nanas (Patola, 2018). Menurut Syakbandini, Nazaruddin, \& Handayani., (2018) warna merupakan parameter pertama yang menentukan tingkat penerimaan suatu produk selain itu penilaian warna secara subyektif juga berpengaruh terhadap penilaian suatu produk, bila warna yang dilihat oleh panelis tidak menarik maka akan menyebabkan rendahnya penilaian panelis terhadap produk tersebut.

\section{Aroma}

Hasil analisis uji sensori menunjukkan bahwa minuman teh cascara dengan penambahan sari nanas memberikan pengaruh nyata $(\mathrm{P}<0,05)$ terhadap aroma yang dihasilkannya. Hasil diuji lanjut yang menunjukkan bahwa $\mathrm{T} 1$ berbeda nyata $(\mathrm{P}<0,05)$ dengan $\mathrm{T} 2$ dan $\mathrm{T} 3$ akan tetapi $\mathrm{T} 2$ tidak berbeda nyata $(\mathrm{P}>0,05)$ dengan $\mathrm{T}$. Berdasarkan hasil uji sensori yang terdapat pada Tabel 2 diketahui bahwa T3 memiliki skor tertinggi yaitu 3,70 (suka), T2 memiliki skor 3,60 (suka), dan untuk T1 memiliki skor 3,10 (netral). Semakin tinggi penambahan sari nanas maka semakin panelis menyukai aroma teh cascara. Aroma yang dihasilkan minuman teh cascara dengan penambahan sari nanas yaitu tercium aroma dari buah nanas. Hal tersebut dikarenakan aroma khas nanas pada perlakuan tersebut dihasilkan oleh komponen volatil yaitu etil dan metil ester (Wibowo et al., 2014). Hal tersebut sesuai menurut Syakbandini et al., (2018) bahwa aroma yang dihasilkan dari suatu produk merupakan aroma khas dari bahan yang digunakan baik bahan utama atau bahan pelengkap.

\section{Rasa}

Hasil analisis uji sensori menunjukkan bahwa minuman teh cascara dengan penambahan sari nanas memberikan pengaruh nyata $(\mathrm{P}>0,05)$ terhadap rasa yang dihasilkannya. Hasil uji lanjut menunjukkan bahwa setiap sampel (T1,T2, dan T3) berbeda nyata $(\mathrm{P}<0,05)$ terhadap tingkat kesukaan warna panelis. Berdasarkan hasil uji sensori yang terdapat pada Tabel 2 diketahui bahwa T3 memiliki skor tertinggi yaitu 3.90 (suka), T2 memiliki skor 3.20 (netral), dan T1 memiliki skor 1.80 (tidak suka). Semakin tinggi penambahan sari nanas maka rasa yang dihasilkan semakin disukai panelis. Menurut Wibowo et al. (2014) hal tersebut dikarenakan penambahan sari nanas dapat menambah cita rasa terhadap sebuah produk dan rasa yang dihasilkan dari sari nanas terdapat pada gula dan kandungan asam pada nanas sehingga akan berpengaruh terhadap bahan yang dicampurkannya.

\section{Kenampakan keseluruhan}

Berdasarkan hasil analisa ragam menunjukkan bahwa minuman teh cascara dengan penambahan sari nanas memberikan pengaruh nyata $(\mathrm{P}<0,05)$ terhadap kenampakan keseluruhan yang dihasilkannya. Hasil uji lanjut menunjukkan bahwa T1 berbeda nyata $(\mathrm{P}<0,05)$ dengan T3 sedangkan $\mathrm{T} 2$ tidak berbeda nyata $(\mathrm{P}>0,05)$ dengan T1 dan T3. Berdasarkan hasil uji sensori yang terdapat pada Tabel diketahui bahwa T1 memiliki skor tertinggi yaitu 3.50 (suka), T2 memiliki skor 3.20 (netral), T3 memiliki skor 2.90 (netral). Data tersebut dapat dikatakan bahwa kenampakan keseluruhan terhadap sampel yang dibuat, rata-rata cukup disukai oleh panelis, meski kenampakan tidak menentukan tingkat kesukaan konsumen secara mutlak akan tetapi kenampakan sendiri mempengaruhi penilaian dari konsumen (Daniela et al., 2015). 


\section{KESIMPULAN}

Berdasarkan hasil analisis yang dilakukan dapat disimpulkan sebagai berikut:

1. Penambahan sari nanas terhadap minuman teh cascara memberikan pengaruh nyata $(\mathrm{P}<0,05)$ terhadap karakteristik kimia (TAT, vitamin $\mathrm{C}, \mathrm{pH}$ ) dengan perlakuan terbaik terdapat pada T3 dengan nilai TAT $0,26 \pm 0,01^{\text {c }}$; vitamin C $68,87 \pm 1,36^{\mathrm{c}}$; dan $\mathrm{pH} 3,89 \pm 0,00^{\mathrm{a}}$. Oleh karena itu, semakin kecil $\mathrm{pH}$ maka semakin tinggi kadar Vitamin C dan TAT.

2. Hasil uji sensori yang dilakukan dapat disimpulkan bahwa pengaruh penambahan sari nanas memberikan pengaruh nyata $(\mathrm{P}<0,05)$ terhadap aroma, rasa dan kenampakan keseluruhan sedangkan pada parameter warna tidak berpengaruh nyata $(\mathrm{P}>0,05)$. Perlakuan terbaik terdapat pada sampel T3 yang rata-rata nya disukai oleh panelis.

\section{DAFTAR PUSTAKA}

Aulya Rohmana, Q., Wahyono, P., \& Hadi, S. (2015). Pengaruh sari buah nanas (Ananas comosus) dan lama penyimpanan terhadap jumlah koloni bakteri dan kadar protein ikan bandeng (Chanos chanos) sebagai sumber belajar dalam perencanaan pembelajaran biologi materi kingdom monera. Jurnal Pendidikan Biologi Indonesia, 1(1), 60 70.

Bastanta, D., Karo-Karo, T., \& Rusmarilin, H., (2017). Pengaruh perbandingan sari sirsak dangan sari bit dan konsentrasi gula terhadap sirup sabit. Jurnal Rekayasa Pangan dan Pertanian, 5(1), 102-108.

Daniela, C., Lubis, L. M., \& Nainggolan, R. J. (2015). Pengaruh perbandingan sari buah nanas dengan melon serta konsentrasi gula terhadap mutu permen jahe (hard candy). Ilmu dan Teknologi Pangan, 3(3), 295-301.
Garis, P., Romalasari, A., \& Purwasih, R. (2019). Pemanfaatan limbah kulit kopi cascara menjadi teh celup. Prosiding Industrial Research Workshop and National Seminar, 10(1), 279-285.

Hayat, I. U., Suryanto, E., \& Abidjulu, J. (2015). Pengaruh sari buah nanas (Ananas comosus L.) terhadap Aktivitas antioksidan pada ekstrak tongkol jagung (Zea Mays L.). Jurnal Ilmiah Farmasi, 4(3), 51-57.

Juansah, J., Dahlan, K., \& Huriati, F. (2009). Peningkatan mutu sari buah nanas dengan memanfaatkan sistem filtrasi aliran dead-end dari membran selulosa asetat. Makara Saiins, 13(1), 94-100.

Kamaluddin, M. J. N., \& Handayani, M. N. (2018). Pengaruh perbedaan jenis hidrokoloid terhadap karakteristik frit leather pepaya. Edufortech, 3(1), 24-32.

Kumalasari, R., Ekafitri, R., \& Desnilasari, D. (2015). Pengaruh bahan penstabil dan perbandingan bubur buah terhadap mutu sari buah campuran pepaya-nanas. Jurnal Hortikultura, 25(3), 266-276.

Nurman, S., Muhajir, D., \& Muhardina, V. (2018). Pengaruh konsentrasi natrium benzoat dan lama penyimpanan terhadap mutu minuman sari buah sirsak (Annona muricata L). Penelitian Pascapanen Pertanian, 15(3), 140-146.

Oktadina, F. D., Argo, B. dwi, \& Hermanto, M. B. (2013). Pemanfaatan nanas (Ananas Comosus L . Merr) untuk penurunan kadar kafein dan perbaikan citarasa kopi (Coffea Sp) dalam pembuatan kopi bubuk. Keteknikan Pertanian Tropis Dan Biosistem, 1(3), 265-273.

Patola, M. K. (2018). Pengaruh konsentrasi sari buah nanas (Ananas comosus (L.) Merr. cv. „Smooth Cayenne") dan susu rendah lemak terhadap kadar asam laktat dan sifat organoleptik yoghurt susu kacang tanah (Arachis hypogaea L.) [Tugas Akhir]. Universitas Sanata Dharma. 
Putri, R. A., \& Anggraeni, E. (2017). Pengembangan pasar minuman cascara ready to drink dengan pendekatan riset aksi [Tugas Akhir]. IPB University Scientific Repository.

Sari, D. L., Murlida, E., \& Aisyah, Y. (2019). Pengaruh rasio kulit buah kopi dan air serta konsentrasi gula terhadap mutu sirup kulit buah kopi. Jurnal Ilmiah Mahasiswa Pertanian , 4(2), 280-289.

Sugiyono. (2013). Metode Penelitian bisnis. Bandung. Alfabeta.

Syakbandini, N., Nazaruddin, \& Handayani., B. R. (2018). Pengaruh konsentrasi starter terhadap teh kambucha sari buah nanas [Thesis]. Universitas Mataram.

Wathon, S. (2019). Peningkatan Nilai Ekonomi kulit buah kopi robusta (Coffea canephora) melalui produksi teh celup cascara sebagai minuman fungsional kaya antioksidan. Warta Pengabdian, 13(4), 123-135. https://doi.org/10.19184/wrtp.v13i4.101 13

Wibowo, R. A., Nurainy, F., \& Sugiharto, R. (2014). Pengaruh penambahan sari buah tertentu terhadap karakteristik fisik, kimia, dan sensori sari tomat. Jurnal Teknologi \& Industri Hasil Pertanian, 19(1), 11-27.

Wiyono, T. S., \& Kartikawati, D. (2018). Pengaruh metode ekstraksi sari nanas secara langsung dan osmosis dengan variasi perebusan terhadap kualitas sirup nanas (Ananas comosus L.). Serat Acitya, 6(2), 108-118. 